\title{
GLOTTODYDAKTYCZNE A LINGWISTYCZNE SPOJRZENIE NA BEĄD JĘZYKOWY
}

\begin{abstract}
Slowa kluczowe: błąd językowy, norma językowa, norma glottodydaktyczna, typologia błędów, błąd leksykalny

Streszczenie. Artykuł dotyczy lingwistycznego i glottodydaktycznego ujęcia błędu językowego. Punktem wyjścia jest stwierdzenie, że stosunek do błędu językowego w nauczaniu języka ojczystego jest inny od tego obecnego w glottodydaktyce. W glottodydaktyce obok normy lingwistycznej jest mowa o zmieniającej się normie glottodydaktycznej, która uwzględnia dydaktyczny punkt widzenia, np. poziom zaawansowania. Następnie zostają przedstawione typologie błędów - jedna obecna w kulturze języka polskiego, jedna klasyfikująca błędy popełniane w języku polskim przez uczniów liceum oraz jedna dotycząca błędów cudzoziemców w języku polskim. Na koniec dokonano zestawienia błędów leksykalnych popełnianych w języku polskim przez rodzimych użytkowników języka z błędami popełnianymi w języku polskim jako obcym.
\end{abstract}

O specyfice nauczania języka polskiego jako obcego pisze się od roku 1966 r., kiedy w „Poradniku Językowym” został opublikowany artykuł pt. Uwagi o nauczaniu języka polskiego jako obcego autorstwa Bronisława Wieczorkiewicza. Autor podkreślał, że nauczanie to różni się znacznie od nauczania polszczyzny jako języka ojczystego, ma natomiast wiele wspólnego z nauczaniem innych języków obcych (Wieczorkiewicz 1966, s. 250). Także podejście do błędu językowego inne jest w literaturze dotyczącej języka polskiego jako ojczystego od tego obecnego w glottodydaktyce polonistycznej / ogólnej.

\section{NORMA LINGWISTYCZNA VS NORMA GLOTTODYDAKTYCZNA}

Błąd językowy w kulturze języka polskiego definiowany jest jako nieświadome odstępstwo od normy bądź innowacja funkcjonalnie nieuzasadniona (SPP 1996, s. XII, Stownik terminologii... 1970, s. 84, Encyklopedia wiedzy... 1978,

" martaskura@uw.edu.pl, Uniwersytet Warszawski, Wydział Polonistyki, Centrum Języka Polskiego i Kultury Polskiej dla Cudzoziemców POLONICUM, ul. Krakowskie Przedmieście 26/28, 00-927 Warszawa, ORCID: 0000-0003-4816-7515. 
s. 34, Butler i in. 1973, s. 18, Porayski-Pomsta 1994, s. 57, NSPP 2000, s. 1621). W glottodydaktyce wielu autorów, m.in. Witold Cienkowski i Aleksander Szulc, podkreśla zasadnicze różnice między błędami popełnianymi w języku ojczystym a błędami popełnianymi w języku obcym, choć wskazują oni także na podobieństwa. W. Cienkowski zwraca uwagę na wspólną obu tym grupom nieuniknioność i naturalność (Cienkowski 1980, s. 441). A. Szulc natomiast pisze o podobnej u użytkownika języka ojczystego i (zwłaszcza w początkowym stadium nauki) użytkownika języka obcego skłonności do hipergeneralizacji wewnątrzjęzykowych (Szulc 1982, s. 262). Elementem różnicującym są przede wszystkim przyczyny powstawania błędów (m. in. interferencja międzyjęzykowa) oraz ich częstotliwość. Poza tym niektórzy autorzy - W. Cienkowski, J. Korzeniewska-Rogalewicz, F. Grucza, E. Zawadzka - zwracają uwagę na normę w języku ojczystym i normę w języku obcym, które nie muszą być identyczne (Grucza 1978, s. 42). Nawiązują oni do pojęcia normy glottodydaktycznej zdefiniowanej przez Krystynę Chomicz-Jung jako: „zbiór parametrów treści glottodydaktycznych zmieniający się $\mathrm{w}$ toku procesu nauczania, uczenia się i przyswajania języka obcego. Zmienność ta jest jej cechą charakterystyczną" (Chomicz-Jung 1990, s. 24). W glottodydaktyce wykorzystywane są obie normy - lingwistyczna i glottodydaktyczna. Za odróżnieniem normy lingwistycznej od normy glottodydaktycznej opowiada się zdecydowanie Elżbieta Zawadzka. Ta pierwsza norma może stanowić podstawę identyfikacji błędów, ale dla nauczycieli języków obcych nie jest wystarczająca przy ocenianiu i poprawie błędów uczniów: „Dla celowości ustalenia błędu, jego rodzaju, przyczyny, a także dla dokonania ewaluacji i/lub korektury błędu niezbędne jest uwzględnienie dydaktycznego punktu widzenia, gdyż lingwistyczna i dydaktyczna definicja błędu nie zawsze się pokrywają" (Zawadzka 2004, s. 251). Autorka pisze dalej, że trzeba reagować w miarę możliwości na każdy błąd w języku obcym, ale nie należy oceniać wszystkich błędów. Punkt odniesienia stanowi norma glottodydaktyczna, która uwzględnia wiele czynników, np. czynniki rozwojowe, interjęzyk ucznia, warunki nauczania.

Pojęcie normy i błędu językowego pojawiają się w kontekście ewaluacji wypowiedzi ucznia. K. Chomicz-Jung w artykule dotyczącym ewaluacji błędu językowego w glottodydaktyce pisze nie o jednej normie, ale o normach glottodydaktycznych, które pełnią podwójną rolę: wyznaczają poziomy wymagań dla danego etapu nauczania oraz stanowią kryteria oceny przyswojonych przez ucznia treści glottodydaktycznych (Chomicz-Jung 1985, s. 154-155).

Podsumowując, w glottodydaktyce nie ma więc, tak jak w kulturze języka jednej stale obowiązującej normy ${ }^{1}$. Normy są tu określane wielokrotnie w za-

${ }^{1} \mathrm{~W}$ kulturze języka polskiego norma także jest różnicowana. H. Kurkowska zaproponowała trzy poziomy normy: potoczno-użytkowy, polszczyzny publicznej i wzorcowy. A. Markowski wyróżnia normę wzorcową i użytkową (Grochala 2015, s. 89). 
leżności od poziomu opanowania języka obcego i celów nauczania. Poza tym pojęcia normy i błędu językowego pojawiają się w kontekście ewaluacji wypowiedzi ucznia.

Odstępstwo od normy glottodydaktycznej jest błędem glottodydaktycznym.

A. Dąbrowska i M. Pasieka odnoszą się do pojęcia normy glottodydaktycznej i błędu glottodydaktycznego (Dąbrowska, Pasieka 2015). Autorki uważają, że pojęcie normy glottodydaktycznej jest zasadne, ale ma przede wszystkim charakter teoretyczny. Uświadamia nauczycielom języka obcego, że nie zawsze ma miejsce korelacja procesu nauczania, uczenia się i przyswajania języka obcego, co powinno wpływać zarówno na ewaluację postępów w opanowaniu języka, jak i korektę przebiegu dydaktycznego. Norma językowa, w odniesieniu do której ocenia się wypowiedzi rodzimych użytkowników języka, ma charakter określany jako całościowy. Norma glottodydaktyczna zaś wyznaczana jest dla różnych poziomów znajomości języka obcego. Błąd glottodydaktyczny jest to błąd popełniany przez cudzoziemca w ramach poziomu kompetencji językowej, na jakim się obecnie znajduje. Nie każdy błąd językowy jest błędem glottodydaktycznym, a czasami jeden i ten sam błąd raz należałby do tej kategorii, raz nie, zależnie od poziomu kompetencji komunikacyjnej osoby, która go popełniła. Błędy wykraczające poza założone treści glottodydaktyczne dla danego poziomu nie mogą być traktowane jako glottodydaktyczne. Można więc z tego wnioskować, że cudzoziemiec popełnia błędy i błędy glottodydaktyczne. Zadaniem nauczyciela jest skorygowanie obu typu błędów, niezależnie od tego, czy popełniający je uczeń wyszedł poza ramy kompetencyjnie swego poziomu. Można jednak przyjąć, że błędy spoza poziomu kompetencji językowej nie powinny wpływać na obniżenie oceny stopnia znajomości języka. To, co jest rozumiane pod pojęciem normy glottodydaktycznej (przejawiającej się częściowo w opisach poziomów kompetencji), może być przydatne przy ewaluacji wypowiedzi językowych cudzoziemców i powodować łagodniejszą ocenę błędów z poziomu wyższego (Dąbrowska, Pasieka 2015, s. 26, 42).

\section{TYPOLOGIE W KULTURZE JEZYKA POLSKIEGO I W GLOTTODYDAKTYCE}

Zdaniem K. Chomicz-Jung zmienna norma glottodydaktyczna stanowi klucz do typologii (Chomicz-Jung 1990, s. 28). Oznacza to, że dla każdego poziomu zaawansowania znajomości języka obcego należałoby ułożyć oddzielną klasyfikację błędów językowych, co w praktyce byłoby bardzo trudne.

Klasyfikacji błędów można dokonać według różnych kryteriów (Komorowska 2005, s. 235-237). Poniżej zostanie pokrótce omówiony podział błędów ze 
względu na system językowy w kulturze języka polskiego, w nauczaniu języka polskiego jako ojczystego i w glottodydaktyce polonistycznej.

$\mathrm{W}$ literaturze przedmiotu można się zetknąć z różnymi typologiami błędów. Podział błędów w kulturze języka polskiego jest bardzo ogólny, pokazuje rodzaje odstępstw od normy i stanowi próbę systematyki. W Nowym słowniku poprawnej polszczyzny błędy zostały podzielone na zewnętrznojęzykowe i wewnętrznojęzykowe. W obrębie pierwszej grupy wymienia się błędy ortograficzne i interpunkcyjne, zaś do drugiej grupy zaliczone zostały błędy systemowe (językowe) i stylistyczne, które autor nazywa błędami użycia. Wśród błędów językowych wyszczególnia błędy gramatyczne (fleksyjne i składniowe), leksykalne (słownikowe, frazeologiczne i słowotwórcze) oraz fonetyczne. Błędy stylistyczne tworzą w tej klasyfikacji oddzielną grupę i polegają na niewłaściwym doborze środków językowych w określonej wypowiedzi, niedostosowaniu ich do charakteru i funkcji wypowiedzi, nie mającej uzasadnienia stylizacji językowej oraz naruszeniu zasad jasności, prostoty i zwięzłości stylu (NSPP, s. 1621-1623). Typologia Markowskiego jest klarowna, spójna i przejrzysta, ale nie jest wystarczająca (nawet) dla wskazania błędów występujących w języku obcym.

Bardziej praktyczny charakter mają typologie stworzone dla potrzeb nauczycieli języka polskiego jako ojczystego, mających trudności z jednoznaczną kwalifikacją błędów uczniów. Wyraźny podział ułatwia bowiem wskazanie i poprawę błędów, a w konsekwencji wpływa na ich eliminację. Typologie te są zwykle wynikiem analizy dużego korpusu błędów uczniowskich. Taki charakter ma podział błędów, wyekscerpowanych z wypowiedzi uczniów liceum ogólnokształcącego, stworzony przez Zygmunta Saloniego (Saloni 1971). Błędy gramatyczne to, jego zdaniem, błędy fleksyjne (morfologiczne) i składniowe. Wśród błędów fleksyjnych wymienia m.in.: niepoprawne używanie zaimków, nieodmienianie nazw własnych, pomieszanie wzorów deklinacyjnych, nieodmienianie liczebników głównych i zbiorowych, błędy w zakresie form czasownika oraz stopniowania przymiotników i przysłówków. Autor zaznacza, że uczniowie popełniają niewiele błędów morfologicznych w porównaniu z licznymi składniowymi i leksykalnymi.

Najwięcej miejsca w swojej publikacji Z. Saloni poświęca błędom składniowym. Jako przyczyny błędów tego typu podaje: atrakcję (przesunięcie granic związku wyrazowego i dodawania określenia do niewłaściwego wyrazu), zagubienie struktury związku wyrazowego i tendencję do skrótu. Wśród błędów składniowych wyróżnia: błędy w zakresie związku zgody, błędy w zakresie związku rządu, błędy w zakresie związku przynależności (sprowadzające się, zdaniem Z. Saloniego, do szyku wyrazów), nadużywanie konstrukcji biernych, błędy w użyciu spójników i zaimków względnych, wykolejenia imiesłowowych równoważników zdania i błędy w zakresie konstrukcji dłuższych odcinków tekstu (błędy naruszające słabsze i luźniejsze związki składniowe, często wychodzące poza granice wypowiedzenia, które są mylnie określane jako stylistyczne lub logiczne). 
Kolejną dużą grupą błędów wyróżnioną przez Z. Saloniego są błędy słownikowe, polegające na niewłaściwym użyciu wyrazów oraz ich związków w dziedzinie semantyki i frazeologii. Autor wymienia tu: błędy w użyciu zaimków i innych wyrazów o znaczeniu relacyjno-gramatycznym, błędy leksykalne oparte na skojarzeniach fonetycznych, błędy słowotwórcze i powstałe skutkiem skojarzeń słowotwórczych, właściwe błędy leksykalne (oparte na mechanizmie semantycznym), błędy w użyciu wyrażeń przyimkowych, wykolejenia łączliwości frazeologicznej wyrazów i zniekształcenia związków frazeologicznych stałych.

Z. Saloni wyszczególnia również błędy stylistyczne, do których zalicza: wieloznaczność sformułowań, skróty myślowe, wielosłowność, powtórzenia wyrazów i konstrukcji, naruszenia konsekwencji gramatycznej oraz niejednolitość stylistyczną. Ostatnią grupą błędów wyróżnianą przez Z. Saloniego są błędy logiczne, które autor nazywa ,językowym odbiciem błędów myślenia” (Saloni 1971, s. 233). Ten typ wykolejeń, zdaniem autora, nie pasuje do wyżej wymienionych kategorii, stoi bowiem na pograniczu błędów w rozumowaniu i błędów językowych.

Z. Saloni podkreśla wielokrotnie w swojej pracy, że często dany błąd wiąże się z dwoma działami gramatyki. Jako przykład podaje wykolejenia rekcji, które można zaliczyć zarówno do gramatyki, jak i do słownictwa (Saloni 1971, s. 21). Trudność sprawia także rozgraniczenie błędów stylistycznych i właściwych błędów językowych. Dlatego też liczne są przypadki zjawisk pogranicznych, niedających się jednoznacznie zaklasyfikować do danego typu błędów. Z. Saloni określa swoją klasyfikację błędów jako roboczą. Podaje liczne przykłady błędów uczniowskich, stara się szukać mechanizmów ich powstawania, pisze także o przyczynach wywołanych regionalnym zróżnicowaniem polszczyzny, niektóre wykolejenia określa mianem „typowych błędów gwarowych” (Saloni 1971, s. 48).

W 2008 r. A. Dąbrowska i M. Pasieka opublikowały pracę pt. Nowa typologia błędów popetnianych przez cudzoziemców w języku polskim, w której przedstawiają bardzo szczegółową klasyfikację, bazującą na dużym korpusie błędów. Autorki dzielą błędy na cztery grupy: błędy formy - rozpoznawalne w izolacji (dotyczące głównie fleksji i słowotwórstwa), błędy użycia - widoczne w konstrukcjach (przeważnie błędy składniowe), błędy leksykalne i stylistyczne.

Autorki wzięły pod uwagę bardzo dużą liczbę błędów - 14 tysięcy - popełnianych przez cudzoziemców mówiących 36 różnymi językami pierwszymi. Zastosowana została metoda indukcyjna - punktem wyjścia był materiał językowy w postaci przykładów błędów, a nie model teoretyczny. Celem badaczek było stworzenie obiektywnej typologii, uwzględniającej większość rodzajów błędów. Same jednak przyznają, że mogą pojawiać się jeszcze nowe grupy błędów, których nie odnotowały, gdyż błędy obcokrajowców są nieprzewidywalne. Okazuje się więc, że trzydzieści dziewięć wymienionych przez autorki grup błędów, podzielonych jeszcze na mniejsze podgrupy i opatrzonych co najmniej jednym przykładem, może okazać się klasyfikacją niekompletną (Dąbrowska, Pasieka 2008a). 
Wobec dużej liczby różnego typu błędów popełnianych przez piszących w języku obcym stworzenie spójnej, klarownej i logicznej typologii jest bardzo trudne, wręcz niemożliwe. Trudno więc nie zgodzić się z Janiną Smólską, która jest następującego zdania: „Autorzy prac o analizie błędów, którzy przedstawiają jej wyniki w postaci idealnie uporządkowanej, bez żadnych luk i niekonsekwencji, bez żadnych wątpliwości i znaków zapytania - tak idealny obraz wyników otrzymać by można jedynie kosztem daleko idących uproszczeń i przemilczeń” (Smólska 1976, s. 84).

W glottodydaktyce pojawiają się zupełnie nowe kategorie błędów, których nie ma w kulturze języka polskiego. A. Dąbrowska i M. Pasieka zaproponowały termin 'błąd pragmatyczny' jako przydatny w opisie wypowiedzi językowych cudzoziemców. Ma on obejmować błędy typu: Polak by tak nie powiedział / nie napisał, czyli błędy stylistyczne, frazeologiczne w szerszym i w węższym znaczeniu, błędy łączliwości semantycznej, błędy szyku o charakterze niesystemowym, tj. podlegające ocenie gorszy / lepszy, a nie poprawny / niepoprawny (Dąbrowska, Pasieka 2008b, s. 112; Dąbrowska, Pasieka 2015, s. 29).

Autorki proponują także wprowadzenie do badań lapsologicznych błędu zwanego 'składniową konstrukcją dysmorficzną' (SKD). Jest to błąd kompleksowy, w którym zaburzenia semantyczne i formalne występują razem. Poprawa SKD jest trudna, konieczna jest bowiem przebudowa całości, w której pojawia się niepoprawna forma gramatyczna składników, niepoprawna rekcja, brak zgody między składnikami, niepoprawny szyk składników, niepoprawne użycie leksemów, naruszenie zasad łączliwości semantycznej. Nie wszystkie cechy muszą wystąpić jednocześnie (Dąbrowska 2012).

Waga poprawnej klasyfikacji, obejmującej najczęściej występujące błędy, w glottodydaktyce jest ogromna, gdyż pozwala na wskazanie i poprawę błędów, a w konsekwencji umożliwia zapobieganie im - choćby częściowe. Typologie występujące w kulturze języka polskiego i nauczaniu języka polskiego jako ojczystego mogą stanowić punkt odniesienia do tworzenia klasyfikacji błędów popełnianych w języku obcym, ale nie są wystarczające. Klasyfikacje błędów obcokrajowców mają charakter otwarty, składają się z licznych grup i podgrup, pojawiają się w nich nowe typy błędów. Dobrym pomysłem jest tworzenie typologii koncentrujących się na błędach cudzoziemców posługujących się danym językiem wyjściowym.

\section{BLĘDY POPELNIANE W JĘZYKU POLSKIM PRZEZ RODZIMYCH UŻYTKOWNIKÓW POLSZCZYZNY I CUDZOZIEMCÓW}

Ostatnia część tekstu stanowi próbę zestawienia przykładów błędów popełnianych $\mathrm{w}$ języku polskim przez rodzimych użytkowników języka z błędami popełnianym w języku polskim jako obcym. Ze względu na obszerność tematu zostaną przywołane wyłącznie przykłady błędów leksykalnych. 
Jeśli chodzi o błędy popełnione przez rodzimych użytkowników języka polskiego, to ich podział i przykłady zostały zaczerpnięte ze strony internetowej Centralnej Komisji Egzaminacyjnej zajmującej się m.in. przygotowaniem egzaminu gimnazjalnego i maturalnego. Materiały dotyczące rażących błędów znajdują się w zakładce Język polski dla nauczycieli² opracowali A. Markowski, I. Burkacka i B. Pędzich.

A. Markowski pisze, co rozumie pod pojęciem 'rażącego błędu leksykalnego', a następnie podaje przykłady błędów tego typu zaczerpniętych z wypowiedzi uczniów oraz wyjaśnia, na czym one polegają ${ }^{3}$.

Za rażący błąd leksykalny uważa takie odstępstwo od wzorcowej normy leksykalnej współczesnej polszczyzny, które odznacza się co najmniej jedną z poniższych cech:

a) powoduje niezrozumiałość fragmentu tekstu, zawierającego taki wyraz, np.:

*Epicentrum w romantyzmie byt człowiek, jego uczucia.

*W tej epoce ukazuje się chtopomania, chtopki wychodza za mąz jak w powieści "Chtopi".

b) powoduje zrozumienie fragmentu tekstu, zawierającego taki wyraz, niezgodne z intencją nadawcy tekstu, np.:

*Barok natomiast to epoka dziet małostkowych, majacych rozbawić.

*Romeo i Julia to tradycyjna opowieść romantyczna, która też zakończyla się śmiercia ich obojgu.

c) powoduje powstanie fragmentu manierycznego albo humorystycznego, np.:

*Izabela wyznaje miłość komuś innemu w towarzystwie Wokulskiego, obcojęzycznie myślac że Stanistaw tego nie rozumie.

*Gustaw umiera i naradza sie ponownie jako Konrad.

d) powoduje powstanie połączenia wyrazowego (kolokacji) wyraźnie naruszającego normę w zakresie łączliwości systemowej bądź normatywnej danego wyrazu, np.:

*Dlatego też w powieściach romantycznych maja miejsce pokazujace się zjawy, duchy.

*Lektura ta opowiada nam historię miłości Wokulskiego do Izabeli Łęckiej.

e) powoduje powstanie połączenia jawnie redundantnego, np.:

*Być może pozytywizm byt tylko chwilowa ,odskoczniq" od romantyzmu, aby ten mógt znowu powrócić.

*Ukazuje on stosunek biurokracji do pojedynczej jednostki.

2 https://cke.gov.pl/egzamin-maturalny/egzamin-w-nowej-formule/materialy-dodatkowe/materialy-dla-uczniow-i-nauczycieli/jezyk-polski-dla-nauczycieli/, [12.06.2018].

${ }^{3} \mathrm{https}$ ://cke.gov.pl/images/_EGZAMIN_MATURALNY_OD_2015/Materialy/Rażące_błędy_językowe_1_LeksFrazSlow.pdf, [12.06.2018]. 
Na koniec omówienia błędów leksykalnych A. Markowski pisze, że odstępstwa od normy leksykalnej wymienione w punktach a)-e) powstają wskutek nierozumienia znaczenia użytego wyrazu, nieznajomości jego łączliwości, używania wyrazów potencjalnych (tworzenia wyrazów) bądź wskutek używania wyrazów modnych.

Ujęcie błędu leksykalnego A. Markowskiego zaprezentowane powyżej wydaje się bardzo szerokie. Gdyby w ten sposób zostały podzielone błędy leksykalne popełnione w języku polskim przez cudzoziemców, powstałaby bardzo duża grupa. Pisząca te słowa przeanalizowała 379 błędów leksykalnych wyekscerpowanych z prac pisemnych Niemców znajdujących się na trzech poziomach zaawansowania: B1, B2 i C2. Za błędy leksykalne uznane zostały jednak tylko błędy wymienione przez A. Markowskiego w podpunktach a)-c). Błędy kolokacji zostały bowiem zakwalifikowane do błędów frazeologicznych, zaś połączenia redundantne, choć mogą świadczyć o niewłaściwym rozumieniu danego elementu, głównie do stylistycznych. Mimo tego dosyć wąskiego rozumienia błędu leksykalnego okazało się, że błędy leksykalne stanowią 20\% wszystkich błędów. Błędy leksykalne, podobnie jak w typologii A. Dąbrowskiej i M. Pasieki (Dąbrowska, Pasieka 2008a), zostały wymienione w każdej grupie błędów przyporządkowanych poszczególnym częściom mowy. Wyróżniono: błędy leksykalne w użyciu czasownika, rzeczownika, przymiotnika, przysłówka, przyimka, spójnika i zaimka. Poniżej zostaną zaprezentowane przykłady błędów leksykalnych w użyciu czasownika i rzeczownika popełnionych przez Niemców piszących po polsku. Niektóre z nich wyraźnie 'demaskują' nadawcę, którego językiem ojczystym nie jest polski. W zebranym materiale językowym znajdują się również takie, które świadczą o dużym prawdopodobieństwie oddziaływania negatywnego transferu z języka niemieckiego. Pojawiają się jednak liczne błędy leksykalne wspólne dla rodzimych użytkowników polszczyzny i cudzoziemców.

a) błędy leksykalne w użyciu czasownika

* Myśle jednak, że trzeba potrafić wykorzystać Internet na właściwy sposób. (C2)

Powyższy błąd może być skutkiem oddziaływania negatywnego transferu z języka niemieckiego, gdyż niemieckim ekwiwalentem polskich czasowników umieć i potrafić jest können. Mamy tu więc do czynienia z sytuacją, w której jednemu wyrazowi w języku niemieckim odpowiadają dwie jednostki leksykalne w języku polskim.

* Dla Polski oznaczyto to wracanie do niewolnictwa, kiedy dopiero kilka lat przed wojna odzyskano wolność po więcej niż sto lat istnienia w podzielonym stanie. (B2)

Powyższy przykład błędu świadczy o tym, że niedokładna znajomość czasowników może powodować zmianę sensu wypowiedzi. 
*On śmiat jak zawsze, i w ostatnich latach nie dużo zmieniat się. (B1)

Nieuzasadnione opuszczanie zaimka się, który w cytowanym wypowiedzeniu pełni funkcję morfemu czasownikowego.

b) błędy leksykalne w użyciu rzeczownika

*W ciagu ostatnich lat jednak coraz więcej byto stychać dzwoniacych telefonów na placach publicznych w sklepach spożywczych lub na czekalniach. (B2)

Polski rzeczownik plac nie posiada wszystkich znaczeń niemieckiego rzeczownika der Platz. Jest to przykład kalki semantycznej powstałej na skutek interferencji z języka niemieckiego.

*[W Londynie] Nie ma problemu z językiem, ponieważ większość ludzkości mówi po angielsku. (B2)

Autor powyższego wypowiedzenia użył rzeczownika, którego znaczenia nie do końca rozumie. Jest to nieudana próba wykazania się wyszukanym słownictwem.

*W ten sposób [reklama] manipuluje nas do kupowania wielu rzeczy na przykład też rzeczy, których nie potrzebujemy, ale kupujemy, bo jest wielka akcja supermarketu. (B2)

Zostało tu przeniesione dodatkowe znaczenie niemieckiego rzeczownika die Aktion, który oprócz znaczenia pokrywającego się z polskim słowem akcja 'zorganizowane działanie podjęte w jakimś celu' [USJP], znaczy jeszcze 'promocja (towarów handlowych)' [Duden, PONS].

Cudzoziemcy są narażeni na mylenie znaczeń wyrazów podobnie brzmiących, np.:

*[użytkownicy Internetu] Nigdy jednak nie moga być pewni, czy inna strona jest tak samo szczera, czy wręcz odwrotnie wymyśla kompletnie nowa osobistość. (C2)

Tego typu błędy popełniają również rodzimi użytkownicy polszczyzny. Błędy leksykalne oparte na skojarzeniach fonetycznych czasami mają szerszy zasięg, ale zwykle są to wykolejenia przypadkowe i indywidualne. Polegają na myleniu i przekręcaniu wyrazów, zazwyczaj pod wpływem błędnego skojarzenia z innymi. Zygmunt Saloni wymienia kilka przykładów tego typu zakłóceń z wypowiedzeń uczniów liceum - sformulowany zamiast sformowany, powszedni-powszechny, solidarnie - solidnie i in. (Saloni 1971, s. 150-151).

Cudzoziemcy popełniają także błędy, które są trudne do wyjaśnienia, np.:

*W komputerach się wybiera danie, smakosz, coctail lub zwykte picie. (B2) pol. smak?

Mogą być one skutkiem błędnych skojarzeń. 
Błędy leksykalne sprowadzają się często do indywidulanych skojarzeń, mających jednak z reguły ogólniejszą przyczynę. Zestawiając błędy popełniane przez osoby posługujące się językiem ojczystym z zakłóceniami obecnymi w wypowiedziach w języku obcym, wyraźnie widać, że te drugie tworzą liczniejszą $\mathrm{i}$ bardziej urozmaiconą grupę. Osoby posługujące się językiem obcym są narażone na oddziaływanie interferencji z języka wyjściowego i wcześniej poznanych języków obcych. Jednak część błędów jest wspólna, co świadczy o zachodzeniu podobnych mechanizmów błędotwórczych, np. skłonności do hipergeneralizacji wewnątrzjęzykowych. Ponadto cudzoziemcy mogą powtarzać nieprawidłowe formy zasłyszane w wypowiedziach rodzimych użytkowników języka.

Przy zestawieniu błędów popełnianych przez rodzimych użytkowników języka polskiego i cudzoziemców warto przytoczyć wyniki badania przeprowadzonego na przełomie lat 2005/2006 wśród polskich maturzystów z kilkunastu polskich liceów ogólnokształcących oraz obcokrajowców zdających egzamin państwowy z języka polskiego jako obcego na poziomie $\mathrm{C} 2$. W wyniku tego badania porównawczego okazało się, że Polacy osiągnęli dużo wyższe wyniki od cudzoziemców jedynie w części: poprawność gramatyczna. Różnice w rezultatach badania słuchania i czytania są niewielkie (na niekorzyść tych drugich). Porównanie wyników sprawności pisania zaskoczyło badających, gdyż okazało się, że w pisaniu znacznie lepsi są obcokrajowcy (Miodunka, Przechodzka 2006). Analiza ta została pogłębiona. Test dla zaawansowanych cudzoziemców (wyłącznie części: czytanie ze zrozumieniem i pisanie) powtórzono w klasach maturalnych w 2009 roku. Uzyskane dane potwierdziły, że kompetencja językowa polskich maturzystów w zakresie testowanych sprawności nie jest satysfakcjonująca - cudzoziemcy ponownie okazali się lepsi od polskich uczniów w zakresie pisania (Przechodzka 2015). Okazało się, że standardy nauczania języka polskiego jako obcego mogą być również przydatne przy opracowaniu europejskich standardów nauczania języka polskiego jako ojczystego (Przechodzka 2015, s. 11).

\section{BIBLIOGRAFIA}

Buttler D., Kurkowska H., Satkiewicz H., 1973, Kultura języka polskiego, t. 1, Warszawa.

Cienkowski W., 1980, Błędy w języku ojczystym a błędy w języku obcym. Terminologia i problematyka, „Poradnik Językowy”, z. 8, s. 441-447.

Chomicz-Jung K., 1985, Glottodydaktyczna ewaluacja błędu językowego, w: F. Grucza (red.), Lingwistyka, glottodydaktyka, translatoryka. Materiaty z VII Sympozjum zorganizowanego przez Instytut Lingwistyki Stosowanej UW Jadwisin 5-7 listopada 1982 r., Warszawa, s. 153-158.

Chomicz-Jung K., 1990, Norma glottodydaktyczna i jej rola w procesie glottodydaktycznym, „Przegląd Glottodydaktyczny", XI, s. 21-38.

Dąbrowska A., 2012, Składniowa konstrukcja dysmorficzna jako błąd kompleksowy, „Poradnik Językowy", z. 6, s. 82-93. 
Dąbrowska A., Pasieka M., 2008a, Nowa typologia błędów popetnianych przez cudzoziemców w języku polskim, w: M. Kita (red.), Bład językowy w perspektywie komunikacyjnej, Katowice, s. $73-102$.

Dąbrowska A., Pasieka M., 2008b, Błędy językowe w tekstach pisanych przez cudzoziemców - wybrane problemy związane z klasyfikacja i ocena, w: A. Seretny, E. Lipińska (red.), Rozwijanie i testowanie biegłości w języku polskim jako obcym, Kraków, s. 103-113.

Dąbrowska A., Pasieka M., 2015, Bład językowy - co to takiego? Rozważania o błędzie językowym w glottodydaktyce polonistycznej, „Acta Universitatis Lodziensis. Kształcenie Polonistyczne Cudzoziemców", t. 22, G. Zarzycka (red.), s. 21-47.

Encyklopedia wiedzy o języku polskim, 1978, S. Urbańczyk (red.), Wrocław.

Grochala B., 2015, Norma wzorcowa vs norma użytkowa a glottodydaktyka, „Acta Universitatis Lodziensis. Kształcenie Polonistyczne Cudzoziemców”, t. 22, G. Zarzycka (red ), s. 87-98.

Grucza F., 1978, Ogólne zagadnienia lapsologii, w: F. Grucza (red.), Z problematyki błędów obcojęzycznych, Warszawa, s. 9-59.

Komorowska H., 2005, Metodyka nauczania języków obcych, Warszawa.

Miodunka W., Przechodzka G., 2006, Kompetencja w języku polskim polskich maturzystów i zaawansowanych cudzoziemców. Badania porównawcze, „Polonistyka”, nr 7 (437 LIX), s. 6-15.

Nowy stownik poprawnej polszczyzny, 2000, A. Markowski (red.), Warszawa [NSPP].

Porayski-Pomsta J., 1994, Błędy językowe i ich rodzaje, w: K. Handke, H. Dalewska-Greń (red.), Polszczyzna a/i Polacy u schyłku XX wieku. Zbiór studiów, Warszawa, s. 55-56.

Przechodzka G., 2015, Kompetencja językowa polskich maturzystów w świetle wyników matur z lat 2005-2008 i testów certyfikatowych dla poziomu zaawansowanego C2, Lublin.

Saloni Z., 1971, Błędy językowe w pracach pisemnych uczniów liceum ogólnoksztatcacego, Warszawa.

Stownik poprawnej polszczyzny, 1996, W. Doroszewski (red.), Warszawa [SPP].

Słownik terminologii językoznawczej, 1970, Z. Gołąb, A. Heinz, K. Polański (red.), Warszawa.

Smólska J., 1976, Aspekt lingwistyczny analizy błędów, w: F. Grucza (red.), Glottodydaktyka a lingwistyka. Materiały z II Sympozjum zorganizowanego przez ILS UW. Jadwisin 13-15 XI 1974, Warszawa, s. 77-88.

Szulc A., 1982, Błąd językowy a dydaktyka języka obcego, „Języki Obce w Szkole”, z. 5, s. 259-266.

Wieczorkiewicz B., 1966, Uwagi o nauczaniu języka polskiego jako języka obcego, „Poradnik Językowy", z. 6, s. 250-255.

Zawadzka E., 2004, Nauczyciele języków obcych w dobie przemian, Kraków.

https://cke.gov.pl/egzamin-maturalny/egzamin-w-nowej-formule/materialy-dodatkowe/materialy -dla-uczniow-i-nauczycieli/jezyk-polski-dla-nauczycieli/, [12.06.2018].

https://cke.gov.pl/images/_EGZAMIN_MATURALNY_OD_2015/Materialy/Rażące_błędy_językowe_1_LeksFrazSlow.pdf, [12.06.2018]. 


\section{Marta Skura}

\section{GLOTTODIDACTIC VS. LINGUISTIC APPROACH TO LANGUAGE ERRORS} cal error

Keywords: language error, linguistics norm, glottodidactic norm, typology of errors, lexi-

Summary. This article concerns the concept of language error in linguistics and in glottodidactics. The starting point is that the approach to language errors in the first language teaching differs from the one prevalent in glottodidactics. Apart from the linguistic norm, glottodidactics also refers to the changing glottodidactic norm, which incorporates a didactic perspective, i.a. proficiency level. Next, three typologies of errors are discussed: one present in Polish-language culture, one classifying errors in the Polish language made by secondary school students, and one for errors in the Polish language made by foreigners. Finally, lexical errors in the Polish language made by native speakers are compared with those made in Polish as a foreign language. 